\title{
IMPROVING STUDENTS' MOTIVATION IN STUDYING ENGLISH USING AUDIO-LINGUAL METHOD
}

\author{
Alfa E. J. Wullur, Nihta V. F. Liando, and Rinny Rorimpandey \\ English Education Department, Manado State Univeristy, Faculty of Language and Arts, Manado State \\ University, Tondano, Indonesia. \\ Email: aveltwe@gmail.com
}

\begin{abstract}
This research is based on the students' motivation in studying English. It intends to prove that students can improve their motivation and it is seen in their achievement in their study. The purpose of this research is to prove that this method is effective in order to improve students' motivation to learn English. This research is conducted at SMP Negeri 11 Bitung. The subject of this research is a seventh-grade student of SMP Negeri 11 Bitung consisted of 24 students. The design of this research is a pre-experimental design with one group pre-test and post-test design. The data are collected through multiple choice as an instrument and with questionnaires and interviews to support the data. In analyzing the data writers use percentage formula. The result of this research shows that the score of the post-test is higher (72.09\%) than the score of the pre-test (44.16\%). Based on the fact of the result of this research, it can be concluded that the Audio-lingual method is effective to be applied in class to improve students' motivation in studying English.
\end{abstract}

Keywords: Teaching; Motivation; Audio-lingual method.

\section{INTRODUCTION}

Language is a communication instrument that effective and efficient in establishing company delivers community members. Without language communication, there is nothing that will work well. Therefore, learning a language is very tender for communication, to help another from various aspects of the existing community or a group of people.

According to Fremont "language is a system of words and grammar used by a group of people. When we write and speak, we are using language". "Language is a system of sound symbols that are meaningful and articulate (produced by spoken devices) that are arbitrary and conventional, which is used as a communication tool by a group of humans to give birth to feelings and thought" (Rombepajung, 2019). Therefore, language as a system of words can be used in every community or groups of people to help every system in government, culture, and education, and for every person to communicate or express their emotions and feeling, especially foreign language including English that is used around the world.

"Foreign language especially English that every people used to express inner thoughts

JELLT (Journal of English Language and Literature Teaching)

Vol. 5 No.01 June 2020

P.ISSN: 2548-7728 E.ISSN: 2599-0373 
and emotions, to make sense of complex and abstract thought, to learn to communicate with other to fulfill our wants or needs, as well as to establish rules and maintain or culture" (Panambunan, Tulung, and Maru, 2016). English is the most widely used language in the world. "Even though in Indonesia, English has not been established as a second language but English is already one of the foreign languages available" (Rorimpandey, 2019). English is one of the foreign languages that have to learn at every level of education in Indonesia because it can be used to communicate with other people. "English as a subject has been introduced in Indonesia from 1945 up to the present time. Teaching English in Indonesia as a foreign language has been focused on developing the four language skills (reading, writing, speaking, and listening) with various degrees of proficiency" (Lambe, 2017).

Mastering these four language skills, namely listening, speaking, reading, and writing, mastering its various components (vocabulary, structure, and pronunciation), and also other supporting aspects in the teaching and learning process are the success of learning English. The motivation in learning English is very important because academic performance depends in large part on non-intellectual factors like attitudes, motivation, and emotional states. Therefore, one of them is motivation. Thus, motivation is one of the important aspects of students in learning English. And underachievement of the study by students is caused by low motivation. From the writers' observation, many students are not motivated to learn.

From the writers' observation and experience, many students get bored when they study English lessons. It can be seen in the lack of attention and participation from the students when the English class and also score the students in English lessons show the lack of motivation to studying English. Many factors make students not have the motivation to learn English because that teacher must have a good personality and a good strategy to make students interest and motivated to learn English lessons.

Motivation cannot be separated from human life. It is an important part of supporting their activity. It can be said that is the center and the source of the whole human activity. And it is the most used concept for explaining the failure or success of a learner. "Student motivation is considered one of the factors contributing to students' success in learning a foreign language" (Liando, 2009). Motivation has been considered as one of the main factors that influence students' success in learning English as a foreign language.

If the students do not have a motivation to learn English, it will make they have a low score for English lesson, and if this situation continues in the future, every student will not know English very well. And it will difficult for them to communicate with other people in another country, so the writer wants to use the audio-lingual method to improve student motivation to learn English.

The audio-lingual method (ALM) is a method that was introduced in the United States of America (USA) in the 1940s. "The method was based on the finding of structural linguistics, who developed psychology and philosophy of language learning different from traditional methods. The combination of the principles of structural linguistic theory, contrastive analysis, aural-oral procedures, and behaviorist psychology was a final development from the

JELLT (Journal of English Language and Literature Teaching)

Vol. 5 No.01 June 2020

P.ISSN: 2548-7728 E.ISSN: 2599-0373 
Audio-lingual method." (Richards and Rodgers, 2001:54-55).

In the Audio-lingual method language learners are equipped with the knowledge and skill required for effective communication in a foreign language. The language learners are also required to understand the foreign people whose language they are learning and the culture of the foreign people. But some experts debate the effectiveness of this method in the education environment.

Many experts said that the Audio-lingual method is not effective in the English learning process, is that true that the method is not effective? But other experts argue that the Audio-lingual method still works and effective in teaching English. Thus, this research writers' wants to analyze that students' motivation will improve using the audio-lingual method and it can be seen in the learning process. This conflict argument leads the research to conduct a study on Improving Students' Motivation In Studying English Using the Audio-Lingual Method.

\section{RESEARCH METHOD}

This research is intended to investigate whether or not the audio-lingual method is effective to improve student motivation to learn English lessons. The design of this research is qualitative, qualitative was used to test this research and to find and prove this research.

This research aims at investigating the motivation of the student before and after the learning, to experiment with the method, and to compare the student motivation of preexperimental design (one group pretest-posttest design), and for supporting the data (answer) of the questionnaire, the writers will use the interview.
The design is shown below.

\begin{tabular}{|c|c|c|}
\hline Pretest & Treatment & Posttest \\
\hline T1 & $\mathrm{X}$ & $\mathrm{T} 2$ \\
\hline
\end{tabular}

One group pretest and posttest design Note :

$\mathrm{T} 1=$ test before the treatment (pretest)

$\mathrm{X}=$ treatment using audio-lingual method

$\mathrm{T} 2=$ test after the treatment (posttest)

The pre-experiment was conducted following this procedure:

1. The teacher gives the student a questionnaire before the treatment

2. Teacher treats and observes students in a first meeting without using the audiolingual method; they treat with the traditional method (lecturing) and for the next meeting using the audio-lingual method.

3. Teacher interviews several students

\section{The subject of the research}

The subject of this research is one class of seventh-grade at SMP Negeri 11 Bitung consisted of 24 students in one class. These 24 subjects responded to the questionnaire. The questionnaire has 30 items.

\section{Data collection}

In collecting the data, the writers use multiple-choice as the instrument, consists of 10 numbers of questions in the test. The first test is a test suitable for the topic, without applying the audio-lingual method. The second test is the post-test after treatment, to know how far the differences between the students' achievement and motivation in learning English. And for supporting the data the writers will use 
interviews and questionnaires with 30 numbers statements.

\section{Questionnaire}

Best (1986), "a questionnaire is used when factual information is desired. Then, the desire information in this research is about the students' motivation in learning English using the audio-lingual method." According to the Oxford dictionary, "a questionnaire is a written list of questions that are answered by several people so that information can be collected from the answers." Based on the definition above, the questionnaire itself consists of several questions related to the motivation of the students in learning English and those questions help the researchers to answer the research question. A motivation questionnaire is used to examine the interest and motivation of the students.

In this research writers use some of the questionnaire items adapted from Gardner, Trembley, and Masgoret (1997), Nender (2006), and Mamentu (2006), Yurah (2010), Tooy (2009). Every questionnaire item used is about motivation, the method that the writers used, and the learning process.

The responses to the questionnaire items were rated as Likert Scale that can be seen below: The positive items, it was rated

\begin{tabular}{|c|c|c|}
\hline \multicolumn{3}{|c|}{ Strongly Agree (SA) } \\
\hline Agree & (A) & \\
\hline Less Agree & (LA) & \\
\hline Disagree & (D) & \\
\hline \multicolumn{3}{|c|}{ For negative items, it was rated } \\
\hline \multicolumn{2}{|c|}{ Strongly Agree (SA) } & \\
\hline Agree & $(\mathrm{A})$ & \\
\hline Less Agree & (LA) & \\
\hline Disagree & (D) & \\
\hline
\end{tabular}

\section{Interview}

An interview is " $a$ conversation, whose purpose is to gather descriptions of the life world of the interviewee" with respect to interpretation of the meaning of the described phenomena. In a similar vein, Schostak, (2006:54) adds, "an interview is an extendable conversation between partners that aims at having in-depth information about a certain topic or subject, and through which a phenomenon could be interpreted in terms of the meanings interviewees bring to it." "Accumulating such meanings can be done in various ways, of which one-on-one interviews are the most common. Besides oneon-one interviews, focus group interviewing is also popular" (Marsall \& Rossman, 2006 in Alshenqeeti, 2014). The interview is used to support the response of the questionnaire and to get more information about the research, and in this research, the writers use closed-questions (closed-interview).

The writers make some questions items based on the research problems and purpose, there are seven questions about the research include motivation, audio-lingual method, and the learning process.

\section{How to collect the data}

The following steps are used by the writers to collect the presentation.

1. Choosing the sample of class

2. Prepare the material and lesson plan. With choosing the material (kompetensi dasar) that relevant to the topic of Descriptive Text "He Has Straight Dark Hair".

3. Giving the questionnaire before the lesson (in this stage, students were asked to respond to the questionnaire) 
4. Giving the treatment by applying the audio-lingual method and a summary of the content of the dialogue and giving questions as the test. The result of the test proved the purpose of this research

5. In the last meeting, the students are interviewed to clarify their answer in the questionnaire, and after the students get the treatment

6. The writers analyze the data to get the result of this research

7. Drawing the conclusion based on the result of the research.

\section{Data analysis}

In analyzing the obtained data, the writers used a percentage formula. The formula is:

$$
P=\frac{F}{N} \times 100
$$

Note: P: Percentage

$\mathrm{N}$ : Frequency

\section{DATA ANALYSIS}

This research takes place in SMP Negeri 11 Bitung. The school is located in Tendeki, kelurahan Tendeki, kecamatan Matuari, kota Bitung. Travel to SMP Negeri 11 Bitung is very difficult to reach by public transportation (mikro, bus) because of being in the research area and being accessible only by private vehicle (or ojek) and on foot. The school is some 40 miles (12.2 $\mathrm{km}$ ) from the city center of Bitung.

This research involves the first-year students of SMP Negeri 11 Bitung who are learning English as a foreign language. It is intended to prove the students' motivation in studying English using the Audio-lingual method.

\section{Tabulating of data}

As the explanation in the previous chapter in this research, the writers use qualitative research by using questionnaires and interviews to supporting the data (answer) in the questionnaire. And for the experiment, the writers use a pre-experimental design (one group pretest-posttest design). The result of the pre-test and post-test are shown in table 1.

Table 1. The data of students in Pre-test (T1) and Post-test (T2)

\begin{tabular}{|c|c|c|}
\hline Students & T1 (Pre-test) & T2 (Post-test) \\
\hline 1 & 40 & 60 \\
\hline 2 & 40 & 60 \\
\hline 3 & 50 & 50 \\
\hline 4 & 50 & 90 \\
\hline 5 & 60 & 90 \\
\hline 6 & 30 & 60 \\
\hline 7 & 50 & 80 \\
\hline 8 & 40 & 70 \\
\hline 9 & 60 & 90 \\
\hline 10 & 50 & 90 \\
\hline 11 & 70 & 80 \\
\hline 12 & 40 & 80 \\
\hline 13 & 20 & 60 \\
\hline
\end{tabular}




\begin{tabular}{|c|c|c|}
\hline 14 & 50 & 70 \\
\hline 15 & 40 & 80 \\
\hline 16 & 70 & 80 \\
\hline 17 & 50 & 60 \\
\hline 18 & 20 & 50 \\
\hline 19 & 50 & 80 \\
\hline 20 & 30 & 60 \\
\hline 21 & 50 & 90 \\
\hline 22 & 30 & 50 \\
\hline 23 & 30 & 70 \\
\hline 24 & 40 & 80 \\
\hline 25 & - & - \\
\hline 26 & - & 1.730 \\
\hline & 1.060 & \\
\hline
\end{tabular}

The table above shows that in class there are 26 students but only 24 students taking the test. All the students who take part in the test could develop their scores in the English test. There is a student who gets the same score on pre-test and post-test. In the pre-test, the highest score is 70 and for the post-test is 90 .

\section{The data of Students Motivation Questionnaire}

There were 24 students as participants in this part of this research. One class in the first year of SMP Negeri 11 Bitung. The students responded to 30 statements in the questionnaire dealing with their motivation in English class.
Each of the states has four options to choose from. Modified Likert-scale is used in scoring each option chosen by the respondent.

The positive items, it was rated

Strongly Agree (SA)

Agree

$=4$

Less Agree

(LA)

$=3$

Disagree

(D)

$=2$

For negative items, it was rated

Strongly Agree (SA)

Agree

(A)

Less Agree

(LA)

Disagree

(D)

$=1$

The score of motivation can be seen below in table 2 .

Table 2. The score of Students Motivation

\begin{tabular}{|c|c|}
\hline $\begin{array}{c}\text { Student } \\
\mathbf{s}\end{array}$ & Score \\
\hline 1 & 97 \\
\hline 2 & 100 \\
\hline 3 & 105 \\
\hline 4 & 102 \\
\hline 5 & 93 \\
\hline 6 & 93 \\
\hline 7 & 99 \\
\hline 8 & 81 \\
\hline 9 & 108 \\
\hline 10 & 95 \\
\hline 11 & 108 \\
\hline & \\
\hline & \\
\hline 10 & \\
\hline 108 \\
\hline 5
\end{tabular}




\begin{tabular}{|c|c|}
\hline 12 & 102 \\
\hline 13 & 103 \\
\hline 14 & 85 \\
\hline 15 & 108 \\
\hline 16 & 111 \\
\hline 17 & 96 \\
\hline 18 & 111 \\
\hline 19 & 105 \\
\hline 20 & 99 \\
\hline 21 & 84 \\
\hline 22 & 93 \\
\hline 23 & 95 \\
\hline 24 & 111 \\
\hline $\operatorname{Max}$ & 111 \\
\hline Min & 81 \\
\hline
\end{tabular}

Table 3 Frequency distribution of Pre-test (T1)

\begin{tabular}{|c|c|c|c|c|c|}
\hline Score & Tally & Frequency & $\begin{array}{c}\text { Cumulative } \\
\text { Frequency }\end{array}$ & $\begin{array}{c}\text { Cumulative } \\
\text { Proportion }\end{array}$ & $\begin{array}{c}\text { Cumulative } \\
\text { Percentage }\end{array}$ \\
\hline 70 & II & 2 & 0.8 & 2 & $8.30 \%$ \\
\hline 60 & II & 2 & 0.16 & 4 & $16.60 \%$ \\
\hline 50 & IIIIIIII & 8 & 0.46 & 12 & $49.90 \%$ \\
\hline 40 & IIIIII & 6 & 0.71 & 18 & $74.90 \%$ \\
\hline 30 & IIII & 4 & 0.87 & 22 & $111.50 \%$ \\
\hline 20 & II & 2 & 0.95 & 24 & $119.80 \%$ \\
\hline
\end{tabular}

Table 3 shows 24 students taking the pretest. The conclusion of the pre-test is 2 students get a high score of 70 as for 2 another students get a score of 60,8 students get a score of 50,6 students get a score of 40, 4 students get a score of 30 and 2 students to get a fairly low grade of 20.

Table 4. Frequency distribution of Post-test (T2)

\begin{tabular}{|c|c|c|c|c|c|}
\hline Score & Tally & Frequency & $\begin{array}{c}\text { Cumulative } \\
\text { Frequency }\end{array}$ & $\begin{array}{c}\text { Cumulative } \\
\text { Proportion }\end{array}$ & $\begin{array}{c}\text { Cumulative } \\
\text { Percentage }\end{array}$ \\
\hline 90 & IIIII & 5 & 0.20 & 5 & $20.83 \%$ \\
\hline 80 & IIIIIII & 7 & 0.49 & 12 & $49.99 \%$ \\
\hline 70 & III & 3 & 0.61 & 15 & $62.49 \%$ \\
\hline 60 & IIIIII & 6 & 0.86 & 21 & $87.49 \%$ \\
\hline 50 & III & 3 & 0.98 & 24 & $99.99 \%$ \\
\hline
\end{tabular}

Table 4 shows that twenty-four students follow the post-test. The conclusions from this post-test describe that 5 students obtain the highest score of 90, 7 students obtain a score of 80,3 students obtain a score of 70, 6 students obtain 60 , and the last 3 students obtain the lowest score of 50 .

The responses to 30 statements on the questionnaire. Student's motivation is described in the following figures 1-30.

\section{Data Questionnaire of Students Motivation}

Students' responses to state that "Belajar Bahasa Inggris sangat menyenangkan" is shown in figure 1.

Figure 1

JELLT (Journal of English Language and Literature Teaching)

Vol. 5 No.01 June 2020

P.ISSN: 2548-7728 E.ISSN: 2599-0373 


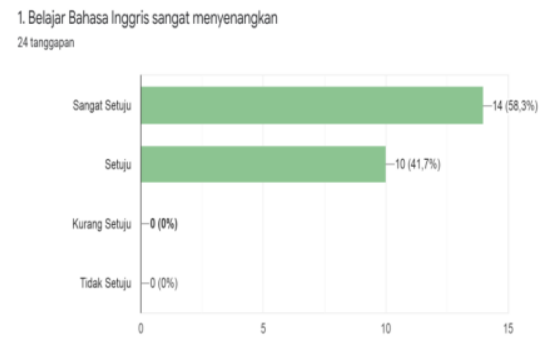

Figure 1 above shows that 14 respondents or $58.3 \%$ answer that strongly agrees to this statement, 10 respondents or $41.7 \%$ give an answer that agrees to this statement, as for less agreed and disagrees, do not get a response from the respondents.

\section{Figure 2}

There a statement that "Anda suka mengajak teman-teman anda berbicara Bahasa Inggris" in present in figure 2 :

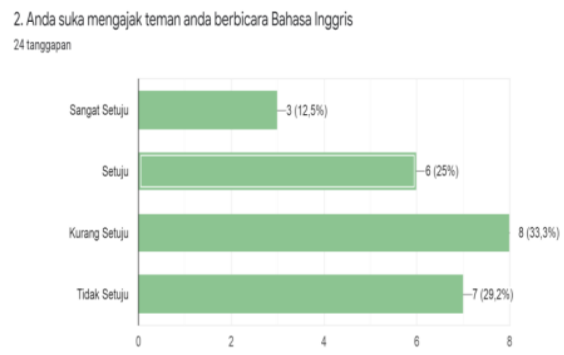

Figure 2 above shows that 8 respondents or $33.3 \%$ answer that less agree to this statement, 7 respondents or $29.2 \%$ give an answer that disagrees with this statement, 6 respondents or $25 \%$ give an answer that agrees to this statement, and 3 respondents or $12.5 \%$ give an answer that strongly agrees to statement.

\section{Figure 3}

There a statement that "Anda mengikuti dengan cermat pembelajaran Bahasa Inggris" in present in figure 3 :

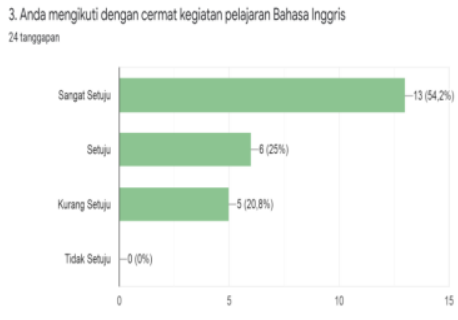

Figure 3 above shows that 13 respondents or $54.2 \%$ answer strongly agree to this statement, 6 respondents or $25 \%$ give an answer that agrees to this statement, 5 respondents or $20.8 \%$ answer that less agree to this statement, as for disagreeing do not have a response from respondents.

\section{Figure 4}

There a statement "Anda suka bertanya pada guru anda jika ada hal yang tidak anda mengerti" in present in figure 4 :

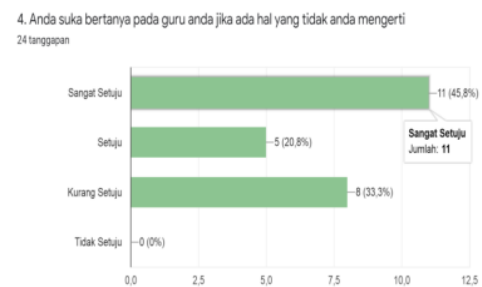

Figure 4 above shows that 11 respondents or $45.8 \%$ answer that strongly agrees to this statement, 8 respondents or $33.3 \%$ answer that less agree to this statement, 5 respondents or $20.8 \%$ give an answer that agrees to this statement, and as for disagreeing do not have a response from respondents.

\section{Figure 5}

There are a statement that "Menurut anda, perlu adanya tambahan waktu/jam pelajaran dalam belajar Bahasa Inggris" in present in figure 5: 


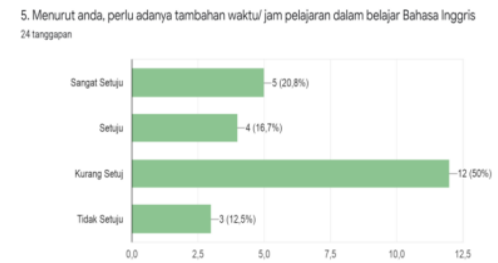

Figure 5 above show that 12 respondents or $50 \%$ answer that less agree to this statement, 5 respondents or $20.8 \%$ give an answer that strongly agrees to this statement, 4 respondents or $16.7 \%$ give an answer that agrees to this statement, and 3 respondents or $12.5 \%$ give an answer that disagrees with this statement.

\section{Figure 6}

There a statement that "Bahasa Inggris tidak perlu dipelajari karena anda bukan orang luar negeri, tetapi orang Indonesia" in present in figure 6 :

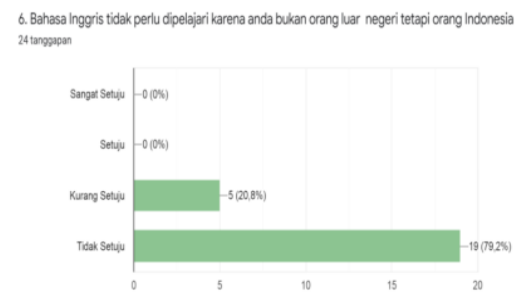

Figure 6 above shows that 19 respondents or $79.2 \%$ answer that disagree with this statement, 5 respondents or $20.8 \%$ give an answer that less agree to this statement, and as for strongly agree and agree do not have a response from respondents.

\section{Figure 7}

There a statement that "Anda tidak suka belajar Bahasa Inggris karena guru yang selalu menggunakan Bahasa Inggris dan tidak menerjemahkannya" in present in figure 7:

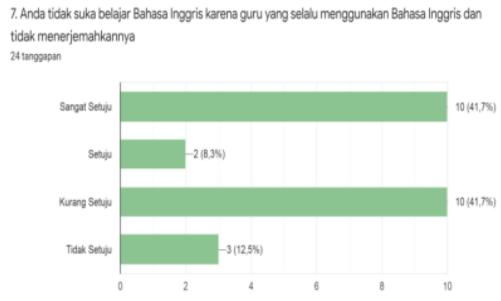

Figure 7 above shows that strongly agree and less agree to have the same score for this statement with 10 respondents or $41,7 \%, 3$ respondents or $12.5 \%$ give an answer that disagrees with this statement, and 2 respondents or $8.3 \%$ give an answer that agrees to this statement.

\section{Figure 8}

There a statement that "Belajar Bahasa Inggris penting, karena banyak manfaat yang anda dapatkan" in present in figure 8 :

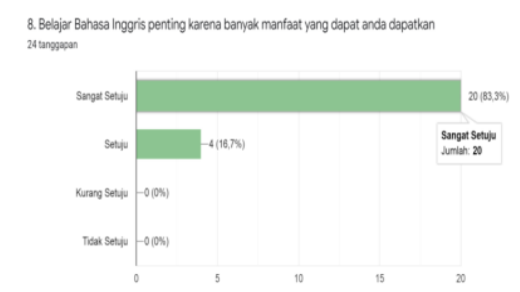

Figure 8 above shows that 20 respondents or $83.3 \%$ answer that strongly agree to this statement, 4 respondents or $16.7 \%$ give an answer that agrees to this statement and as for less agree and disagree do not have a response from respondents.

\section{Figure 9}

There a statement that "Anda tidak memiliki minat dalam belajar Bahasa Inggris" in present in figure 9: 


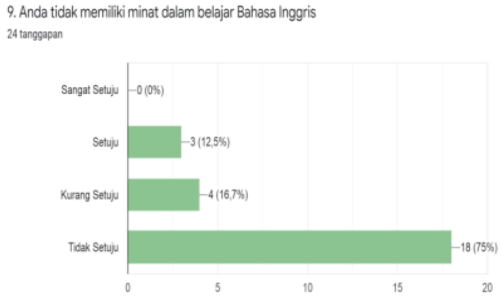

Figure 9 above shows that 18 respondents or $75 \%$ answer that disagree with this statement, 4 respondents or $16.7 \%$ answer that less agree to this statement, 3 respondents or $12.5 \%$ give an answer that agrees to this statement, and as for strongly agree do not have a response from respondents.

\section{Figure 10}

There a statement that "Bahasa Inggris adalah mata pelajaran favorit anda" in present in figure 10:

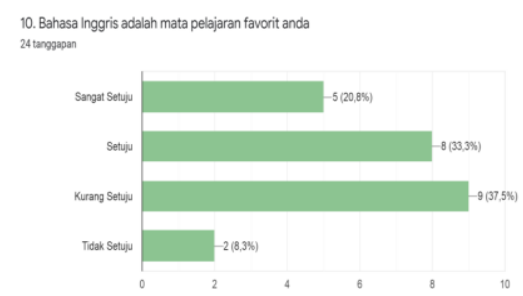

Figure 10 above shows that 9 respondents or $37.5 \%$ answer that less agree to this statement, 8 respondents or $33.3 \%$ give an answer that agree to this statement, 5 respondents or $20.8 \%$ give an answer that strongly agree to this statement, and 2 respondents or $8.3 \%$ give an answer that disagrees to this statement.

\section{DISCUSSION OF THE RESULT}

From the in-depth observation, the writers find that first-year students' motivation is low in studying English and the writers want to use the Audio-lingual method to improve their motivation. And in this research, the writers want to prove that students motivation can improve and it can be seen in students score when their study.

Motivation is an energy that impels someone to do something constantly to achieve his or her goals. The method that the writers used in this research is the Audio-lingual method, this method is a method to teach a foreign language by teaching students by its habit that the students can learn and mastered something along with their habit of doing it over and over again.

And in this research, the writers can prove that students' motivation improved. According to Liando, "If students are highly motivated they will work harder to achieve better academic performance". Therefore, encouraging students to study harder and better and motivating them to learn will impact their learning performance to achieve a high value. "The teacher environment and atmosphere at home is can be an important role in motivating students to study well" (Liando ,2009).

In this research, the writers are experiencing some of the challenges of the research process, one of which is the impact of covid-19 has a profound impact on students' learning around the world, in Indonesia especially at the school that the writers research. Therefore the school also provides leniency and suggests for the writers to continue the research using a recording video like the teacher who teaches in the school. The writers thus makes a video according to the running curriculum and according to the direction of the English teacher in the studied class, by simple video, the writers use social media research, from giving a test, questionnaire, and interview with a telephone.

The conclusions of this research portrays that first grade of SMP Negeri 11 Bitung has 
improved their motivation in studying English. The writers use multiple-choice as a test. There are twenty-six (26) students in class but just twenty-four (24) students who take a part in the test. On the highest pre-test score is 70 obtained by two students and the lowest score is 20 obtained by two students as well. The highest post-test score by five students is 90 and the lowest score get by three students is 50 . From this it can be seen that there is a significant difference between student's academic achievement on pretest and post-test, indicate that $72.09 \%$ of the student's values have improved. And these results are allegedly supported by questionnaires and interviews with students.

\section{CONCLUSION}

Based on the analysis and the data shown in the previous chapter, it is should be concluded that the student's value on post-test (T2) is higher than the value on pre-test (T1). The count of pretest (T1) percent is $44.16 \%$ and for post-test (T2) is $72.09 \%$. it means that the students' motivation in studying English is improved.

With the use of Audio-lingual method it can make students speak foreign language especially English orally in a short time and focus in the learning process because using audio and visual in teaching, and with using videos students not only learn listening but they learn speaking, reading, etc. in videos writer explain the important things about the topics that they learn and about the main topics with the example so students can understand it, then the writers put the audio when she explains the topics and she read the dialog so students can listen to it well. In the audio-lingual method, many techniques can make the teaching and learning process is enjoyable, interesting, creative, and effective to teach students (drills, dialog, roleplay, using audio, videos, etc).

From the results of the research, the method might be one of the influential factors in improving students' motivation.

\section{REFERENCES}

Alshenqeeti, H. (2014). Interviewing as a Data Collection Method: A Critical

Review. (Vol. 3, No. 1). United Kingdom: Sciedu Press Best, J. W. (1977).Research in Education (3 ${ }^{\text {rd }}$ $E d$.)New Jersey: Prentice Hall, Inc. Englewood cliffs

Gardener, R. C., \& Lambert, W. C. (1972).Attitudes and Motivation in Second language learning. Rowley, MA: Newburry House

Lambe, L. 2017. Teaching Reading Comprehension In EFL Classroom: A Glance At Some Approaches And . 2, No.

2. Indonesia: Universitas Negeri Manado

Larsen-Freeman, D. (2000). Techniques and Principles in Language Teaching. Oxford: OxfordUniversity Press

Liando, N. V. F., (2009). Students' Perspectives on Motivation to Learn English. Celt, Vol. 9, No. 2. (150-169). Indonesia: Manado State University

Liando, N. V. F., Moni. K. B., \&Baldauf, J. R. B. (2005). Students Motivation in LearningEnglish As A Foreign Language in An Indonesian Context. In J. Yamanashi \& I. Milojevic (Eds), Researching Identity, Diversity \& Education: Surpassing The Norm. (pp. 168-179). Tenerife: Post Pressed

Mart, C. T. (2013).The Audio-lingual method: 
AN Easy Way of Achieving Speech.

(Pp.63).Iraq: Department of Language Ishik University

Nender, E. (2006). A Study on Students'

Motivation in Learning English.

Tondano:UNIMA

Panambunan, E., Tulung, G. J., \&Maru, M. G.

(2016).Improving Students' Ability

ThroughCommunicate Language

Teaching of The second Level Students at 'MEC' Megalia English Course. Vol.

1, No.1. Indonesia: Manado State University

Richards, J \& Rodgers, T. (2001).Approaches

and Methods in Language

Teaching. (p. 54-55).Cambridge:

Cambridge University Press

Rombepajung, P. A., (2019). Use of Jigsaw

Model in Improving Reading

Understanding in FBSUNIMA English

Students.Vol.4, No. 1. Indonesia:

Manado State University

Rorimpandey, R., (2019). Youtube Videos in

Teaching Basic Listening. Vol.4, No.

1. Indonesia: Manado State University

Tooy, F. (2009).Improving Students' Motivation

in Learning English Through

Inquiry Strategy. Tondano: English

Education Department UNIMA

Yurah, F. V. (2010). Motivasi Belajar Bahasa

Prancis Siswa SMA Negeri 2

Manado. Tondano: UNIMA

Https://www.vocabulary.com/dictionary

/John\%20C.\%20Fremont (online)

Retrieved on 16 July/2019 at 9 p.m

JELLT (Journal of English Language and Literature Teaching)

Vol. 5 No.01 June 2020

P.ISSN: 2548-7728 E.ISSN: 2599-0373 